\title{
Distribution and density of demersal fishes in Youtefa Bay, Papua, Indonesia: A study using hydroacoustic technology
}

\author{
BAIGO HAMUNA ${ }^{1}$, SRI PUJIYATI ${ }^{2}$, LISIARD DIMARA ${ }^{1}$, NYOMAN METTA N. NATIH² AND \\ ALIANTO $^{3}$ \\ ${ }^{1}$ Department of Marine Science and Fisheries, Cenderawasih University, Kamp Wolker Street \\ Jayapura City - 99351, Papua, Indonesia \\ ${ }^{2}$ Department of Marine Science and Technology, Bogor Agricultural University, Lingkar Kampus IPB \\ Bogor - 16680, West Java, Indonesia \\ ${ }^{3}$ Department of Fisheries, University of Papua, Gunung Salju Street, Manokwari 98314, West Papua, Indonesia \\ e-mail: bhamuna@yahoo.com.sg
}

\begin{abstract}
A study was conducted to estimate the distribution and density of demersal fish in Youtefa Bay, Papua, Indonesia, using hydroacoustic technology. The hydroacoustic survey was carried out using a single beam echosounder SIMRAD EK-15 which operates at a frequency of $200 \mathrm{kHz}$. The hydroacoustic data was processed using Echoview software with a threshold between -70.00 to $-34.00 \mathrm{~dB}$. Schooling fish were detected at a maximum distance of $3 \mathrm{~m}$ from the seabed, with average volume backscattering strength ranging between -60.13 and $-42.01 \mathrm{~dB}$. The demersal fish density in the Youtefa Bay ranged from 0.09 to 42.19 fish $\mathrm{m}^{-3}$ with an average density of $12.62 \mathrm{fish} \mathrm{m}^{-3}$. The schools of demersal fish were dominantly detected in the coastal waters of Enggros Village to Abe Pantai Village. The condition of substrate and water depth seems to influence the spatial and vertical distribution of demersal fish in the Youtefa Bay.
\end{abstract}

Keywords: Demersal fish, Fish schooling, Hydroacoustic technology, Volume backscattering strength, Youtefa Bay

\section{Introduction}

Youtefa Bay in Papua Province, Indonesia supports several fish species. But the local fishermen have not been able to utilise the potential of these resources optimally, due to lack of accurate information on fish distribution in the Bay. Hydroacoustic technology has been often utilised for fish characterisation and classification and fisheries surveys (Davison et al., 2015; Thompson et al., 2015; Melvin, 2016; Pujiyati et al., 2016; Wurtzell et al., 2016) and for analysis and mapping of the seabed (Pujiyati et al., 2007; Cutter and Demer, 2014; Calvert et al., 2015; Hamuna et al., 2018a, b).

Measurement of fish population density has important applications especially for studying and management of fisheries (Gunderson, 1993). Hydroacoustic technology is considered to be an efficient fishery survey method to overcome the limitations of traditional survey methods (Hewitt et al., 2002) and has several advantages compared to the swept area trawl method because it can detect wider water columns continuously and simultaneously (McQuinn et al., 2005). The utilisation of hydroacoustic technology for fishing is one of the effective methods to detect the existence of fish directly, quickly and accurately (Simmonds and MacLennan, 2005) and to study the fish and their habitat (Pujiyati, 2008).
The objective of the present study was to apply hydroacoustic technology to estimate the distribution and density of demersal fish in Youtefa Bay, Indonesia as such information is very important for fisheries management. The results of this study can support formulating strategies for the management of demersal fish resources in the Youtefa Bay and is expected to help the local fishermen in the Youtefa Bay to identify potential areas for demersal fishing activities.

\section{Materials and methods}

This study was conducted in April 2017 in Youtefa Bay waters, in Jayapura, Papua, Indonesia. Hydroacoustic data recording was carried out in Youtefa Bay along $12.51 \mathrm{~km}$ of the survey line (Fig. 1), using a single beam echosounder SIMRAD EK-15 $(200 \mathrm{kHz})$. Instrument specification and parameter setting during hydroacoustic data recording are listed in Table 1. Hydroacoustic data acquisition was carried out continuously with a maximum ship speed of 4-5 knots.

The Echoview 4.8 software was used for processing data. The elementary sampling distance unit (ESDU) used in data processing was 100 pings (Mello and Rose, 2009) and the hydroacoustic data obtained was divided into 320 


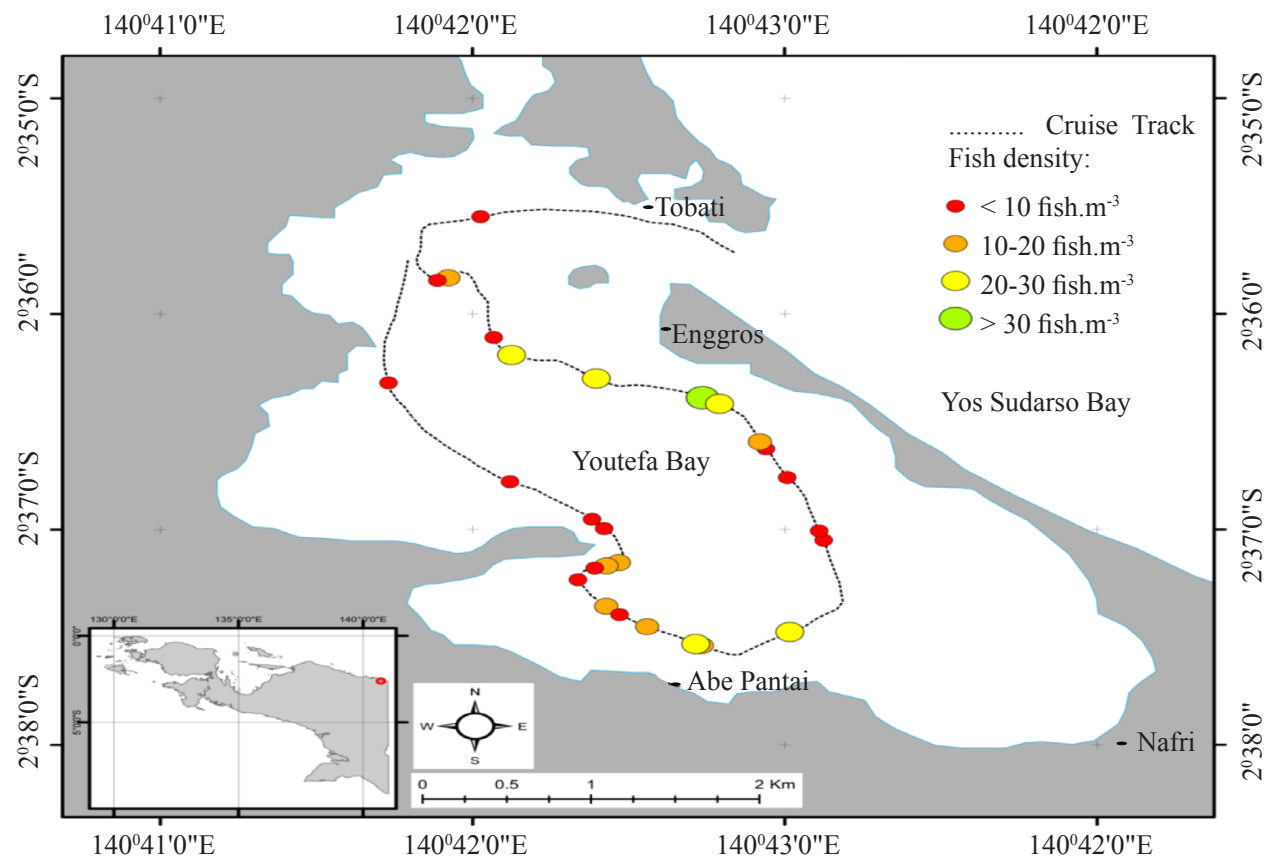

Fig. 1. Hydroacoustic cruise track and spatial distribution of demersal fish in Youtefa Bay, Indonesia

Table 1. Parameters settings during the hydroacoustic survey

\begin{tabular}{ll}
\hline Parameter & Value \\
\hline Frequency $(\mathrm{kHz})$ & 200 \\
Power transmit (watt) & 50 \\
Beam width (deg) & 26 \\
Transducer depth (m) & 0.5 \\
Ping rate $(\mathrm{Hz})$ & $>40$ \\
Pulse length (ms) & 0.160 \\
Pulse duration (ms) & 0.128 \\
Sound velocity (m s & 1545.87 \\
Absorption coefficient $\left(\mathrm{dB} \mathrm{m}^{-1}\right)$ & 0.01872 \\
Transducer gain $(\mathrm{dB})$ & 14.20 \\
\hline
\end{tabular}

ESDU. The processing data used a minimum threshold of $-70.00 \mathrm{~dB}$ and a maximum of $-34.00 \mathrm{~dB}$ (Manik and Nurkomala, 2016; Park et al., 2016). Considering that the habitat of demersal fish is at the seabed or near the seabed, integration and analysis of hydroacoustic data was focused at a distance of $3 \mathrm{~m}$ from the seabed. Distance from the seabed was added to $0.12 \mathrm{~m}(c \tau / 2 ; c=$ sound velocity; $\tau=$ pulse length) above the seabed line detected in order to avoid the entry of sea bed echo.

Target strength (TS) and volume backscattering strength (Sv) are important parameters for estimating fish densities. TS is a logarithmic measure of the proportion of the incident energy which is backscattered by the target (Simmonds and MacLennan, 2005). Sv is the key measurement for estimation of acoustical fish density and abundance (Parker-Stetter et al., 2009). The accuracy of
TS determines the accuracy of estimates of fish density and abundance (Kim et al., 2018). Data on the length of demersal fish (L) obtained in this study was used to determine the TS value of demersal fish using the following equation (Hjellvik et al., 2003):

$$
\mathrm{TS}=20 \log \mathrm{L}-68
$$

The TS value thus obtained was converted into a backscattering cross section $\left(<\sigma_{\mathrm{bs}}>\right)$ by linearising the TS value using the following equations (Simmonds and MacLennan, 2005):

$$
\begin{aligned}
& \mathrm{TS}=10 \log _{10}\left(\sigma_{\mathrm{bs}}\right) \\
& \sigma_{\mathrm{bs}}=10^{(\mathrm{TS} / 10)}
\end{aligned}
$$

The result of data processing was an acoustic data matrix of Sv from fish schooling. The logarithmic equation for measuring $\mathrm{Sv}$ value and volume backscattering coefficient $\left(\mathrm{s}_{\mathrm{v}}\right)$ is as follows:

$$
\begin{aligned}
& \mathrm{Sv}=10 \log _{10}\left(\mathrm{~s}_{\mathrm{v}}\right) \\
& \mathrm{s}_{\mathrm{v}}=10^{(\mathrm{Sv} / 10)}
\end{aligned}
$$

The spatial and vertical distribution of demersal fish in Youtefa Bay during hydroacoustic surveys has been presented. Grouping of demersal fish density in each range of $5 \mathrm{~m}$ depth was done to find out the distribution in each of these depth ranges. The density of fish was calculated using Sv and $\sigma b s$ values. This method is sometimes referred to as Sv/TS scaling considering that this density estimate depends on the value of the integration of echo (Sv) and 
obs. The Sv is defined as fish density $(\rho)$ multiplied with the average backscattering cross section $(<\sigma b s>)$ (ParkerStetter et al., 2009):

$$
\mathrm{s}_{\mathrm{v}}=\rho v \cdot<\sigma_{\mathrm{bs}}>
$$

The density of demersal fish per unit volume ( $\rho v)$ was obtained using the following equation (Parker-Stetter et al., 2009):

$$
\rho v=\mathrm{s}_{\mathrm{v}} /<\sigma_{\mathrm{bs}}>
$$

\section{Results}

\section{Detection of demersal fish schooling}

During the hydroacoustic survey, 27 schools of demersal fish were recorded. The position of demersal fish schools based on water depth is presented in Table 2. Based on the result of hydroacoustic detection, schooling of demersal fish was found in the shallow waters of Youtefa Bay. The schools of demersal fish in the Youtefa Bay were found at an average distance of $0.26-2.93 \mathrm{~m}$ above the sea bed with the height of the schools ranging between 0.49 and $1.70 \mathrm{~m}$. Based on the integration results for demersal

Table 2. The demersal fish school depth of occurrence based on

\begin{tabular}{|c|c|c|c|}
\hline No & ESDU & Water depth (m) & $\begin{array}{l}\text { Demersal fish } \\
\text { school depth (m) }\end{array}$ \\
\hline 1 & 31 & 34.53 & 33.44 \\
\hline 2 & 62 & 28.85 & 27.07 \\
\hline 3 & 78 & 12.15 & 11.70 \\
\hline 4 & 81 & 11.68 & 10.20 \\
\hline 5 & 90 & 7.93 & 6.66 \\
\hline 6 & 92 & 8.71 & 6.72 \\
\hline 7 & 94 & 8.92 & 7.48 \\
\hline 8 & 98 & 8.92 & 8.17 \\
\hline 9 & 106 & 8.41 & 6.47 \\
\hline 10 & 109 & 8.21 & 7.58 \\
\hline 11 & 114 & 7.73 & 5.46 \\
\hline 12 & 123 & 7.17 & 4.54 \\
\hline 13 & 124 & 7.09 & 5.39 \\
\hline 14 & 141 & 7.32 & 6.30 \\
\hline 15 & 168 & 9.58 & 8.78 \\
\hline 16 & 170 & 9.94 & 7.01 \\
\hline 17 & 184 & 9.27 & 7.36 \\
\hline 18 & 192 & 9.03 & 7.33 \\
\hline 19 & 194 & 7.73 & 5.47 \\
\hline 20 & 206 & 5.24 & 4.33 \\
\hline 21 & 209 & 4.61 & 3.34 \\
\hline 22 & 227 & 5.90 & 4.26 \\
\hline 23 & 242 & 4.60 & 4.34 \\
\hline 24 & 247 & 13.78 & 11.29 \\
\hline 25 & 266 & 8.13 & 5.27 \\
\hline 26 & 268 & 15.70 & 15.00 \\
\hline 27 & 290 & 8.08 & 7.55 \\
\hline
\end{tabular}
echo integration fish, $\mathrm{Sv}$ values obtained ranged from -60.13 to $-42.01 \mathrm{~dB}$ with an average $\mathrm{Sv}$ value of $-54.66 \mathrm{~dB}$.

Demersal fish distribution in the Youtefa Bay

The vertical distribution of $\mathrm{Sv}$ value for demersal fish schools is presented in Table 3. The spatial distribution of demersal fish was recorded mainly in the coastal waters from Enggros to Abe Pantai villages (Fig. 1). The Sv values of demersal fish were in the range of -59.00 to $-52.00 \mathrm{~dB}$. High Sv value ( $>-43 \mathrm{~dB}$ ) was only found at one school around the waters of Tobati Village. The high number of demersal fish detected in the coastal waters from Enggros to Abe Pantai villages could be due to the influence of the seabed substrate, which was dominated by seagrass and mud.

\section{Demersal fish density in the Youtefa Bay}

The demersal fish aggregations could be clearly seen on echograms, through hydroacoustic detection. The vertical distribution of demersal fish density in Youtefa Bay is presented in Table 4. Based on 320 ESDU which contained 27 fish schools, highest demersal fish density

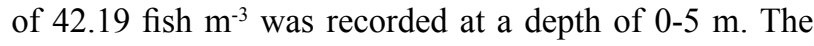
average density of demersal fish detected in Youtefa Bay waters was $12.62 \mathrm{fish} \mathrm{m}^{-3}$.

\section{Discussion}

Results of the study indicate that in Youtefa Bay, demersal fish abundance was comparatively more in shallow waters and decreased with increase in water depth. The density of demersal fish was concentrated at the depths upto $10 \mathrm{~m}$. The detected size of demersal fish in Youtefa Bay was small. This explains that small fish prefer shallow water zones as their habitat (Chang et al., 2012). Small demersal fish are important in marine ecosystems in connecting the lower and upper levels in the food chain (Thangavelu et al., 2012; Chouvelon et al., 2015).

There are 36 demersal fish families that were caught by local fishermen in the Youtefa Bay, which is mostly commercial fish (Tebaiy et al., 2014). Commercially important fish were dominant in the shallow water zone (Labropoulou and Papaconstantinou, 2004). The dominant species caught by local fishermen are Siganus fuscescens, S. canaliculatus, Apogon ceramensis, Mugil cephalus, Aeoliscus strigatus, Scolopsis lineata, Parupeneus barberinus, Atherinomorus lacunosus and Upeneus subvittatus.

The high number of demersal fish detected in the present stduy, in the coastal waters from Enggros Village to Abe Pantai Village was probably because of the nature of sea bed. The shallow water habitat at the location of 
Table 3. Vertical distribution of demersal fish schools based on hydroacoustic detection in Youtefa Bay, Indonesia

\begin{tabular}{|c|c|c|c|c|c|c|c|c|}
\hline \multirow{2}{*}{$\mathrm{Sv}(\mathrm{dB})$} & \multicolumn{7}{|c|}{ Demersal school depth (m) } & \multirow{2}{*}{ No. of fish schools } \\
\hline & $<5$ & $5-10$ & $10-15$ & $15-20$ & $20-25$ & $25-30$ & $>30$ & \\
\hline$>(-43)$ & - & 1 & - & - & - & - & - & 1 \\
\hline$(-43)-(-46)$ & - & - & - & - & - & - & - & - \\
\hline$(-46)-(-49)$ & - & 1 & - & - & - & - & - & 1 \\
\hline$(-49)-(-52)$ & 1 & 1 & 1 & - & - & - & 1 & 4 \\
\hline$(-52)-(-56)$ & 2 & 6 & 1 & - & - & - & - & 9 \\
\hline$(-56)-(-59)$ & 2 & 5 & 1 & 1 & - & 1 & - & 10 \\
\hline$<(-59)$ & - & 2 & - & - & - & - & - & 2 \\
\hline
\end{tabular}

Table 4. Demersal fish density based on hydroacoustic detection in Youtefa Bay, Indonesia

\begin{tabular}{lllll}
\hline \multirow{2}{*}{ Demersal schooling depth $(\mathrm{m})$} & \multirow{2}{*}{ ¿ Schools } & \multicolumn{3}{c}{ Fish density $\left(\right.$ Fish $\left.\mathrm{m}^{-3}\right)$} \\
\cline { 3 - 5 } & & Average & Max. & Min. \\
\hline $5-10$ & 5 & 28.37 & 42.19 & 22.91 \\
$10-15$ & 16 & 11.49 & 28.54 & 0.09 \\
$15-20$ & 3 & 3.95 & 4.59 & 3.50 \\
$20-25$ & 1 & 2.13 & 2.13 & 2.13 \\
$25-30$ & - & - & - & - \\
$>30$ & 1 & 0.65 & 0.65 & 0.65 \\
\hline
\end{tabular}

this study is dominated by seagrass. Habitat is important and influences the distribution of demersal fish (van der Kooij et al., 2011). Seagrass vegetation and presence of benthic invertebrates in the fish habitat support fish abundance (Gillanders, 2006; Goldman and Sedberry, 2011). The substrate type is very important in controlling the distribution of demersal fish because it affects the distribution of invertebrates which are important as fish food (Lowe-McConnell, 1987).

Several studies have shown that there is a high correlation between demersal fish distribution and water depth (Rainer and Munro, 1982; Moore et al., 2009; Suyatna et al., 2010; Zintzen et al., 2012; Samphan, 2016). The results of hydroacoustic surveys in Indonesia at a depth of 5-40 m have shown similar results, where demersal fish are dominant in shallow waters (Fahmi, 2008; Pujiyati, 2008). Shifts in the abundance and richness index of demersal fish have also been associated with a water depth gradient (Labropoulou and Papaconstantinou, 2004; Sudhakar et al., 2013; Perangin-angin et al., 2017).

The results of this study provide baseline information on the distribution and density of demersal fish in Youtefa Bay waters, based on hydroacoustic survey, which will be useful to make fisheries management policies and to help the local fishermen to identify potential areas for demersal fishing activities in the bay.

\section{Acknowledgments}

The authors thank the Ministry of Research, Technology and Higher Education of the Republic of Indonesia for funding this study (Grant No. 01/ UN20.2.2/PP/PKPT/2018). The authors also thank Asep Mamun (Ministry of Marine and Fisheries Affairs, Republic of Indonesia) who helped in hydroacoustic data acquisition, and the students of Marine Science Program (Cenderawasih University) who were involved in research for field data acquisition.

\section{References}

Calvert, J., Strong, J.A., Service, M., McGonigle, C. and Quinn, R. 2015. An evaluation of supervised and unsupervised classification techniques for marine benthic habitat mapping using multibeam echosounder data. ICES J. Mar. Sci., 72(5): 1498-1513.

Chang, N. N., Shiao, J. C. and Gong, G. C. 2012. Diversity of demersal fish in the East China Sea: Implication of eutrophication and fishery. Cont. Shelf Res., 47: 42-54.

Chouvelon, T., Violamer,L.,Dessier,A.,Bustamante,P., Mornet,F., Pignon-Mussaud, C. and Dupuy, C. 2015. Small pelagic fish feeding patterns in relation to food resource variability: an isotopic investigation for Sardina pilchardus and Engraulis encrasicolus from the Bay of Biscay (northeast Atlantic). Mar. Biol., 162(1): 15-37. http://dx.doi. org/10.1007/s00227-014-2577-5.

Cutter, Jr. G. R. and Demer, D. A. 2014. Seabed classification using surface backscattering strength versus acoustic frequency and incidence angle measured with vertical, split-beam echosounders. ICES J. Mar. Sci., 71(4): 882-894.

Davison, P. C., Koslow, J. A. and Kloser, R. J. 2015. Acoustic biomass estimation of mesopelagic fish: backscattering 
from individuals, populations and communities. ICES J. Mar. Sci., 72(5): 413-1424. doi:10.1093/icesjms/fsv023.

Fahmi, Z. 2008. Estimation of density and distribution of demersal fish using acoustic method in Belitung waters. $B A W A L, 2(2):$ 63-68 [In Indonesian].

Gillanders, B. M. 2006. Seagrasses, fish and fisheries. In: Larkum, A. W. D., Orth and Duarte, R. J. M. (Eds.), Seagrasses: biology, ecology and conservation. Springer, Netherlands, p. 503-530.

Goldman, S. F. and Sedberry, G. R. 2011. Feeding habits of some demersal fish on the Charleston Bump off the south-eastern United States. ICES J. Mar. Sci., 68(2): 390-398.

Gunderson, D. R. 1993. Surveys of fisheries resources. John Wiley and Sons, New York, USA, 248 pp.

Hamuna, B., Dimara, L., Pujiyati, S. and Natih, N. M. N. 2018a. Correlation of substrate fraction percentage with acoustic backscattering strength from single beam echosounder detection. AACL Bioflux, 11(4): 1343-1351.

Hamuna, B., Pujiyati, S., Natih, N. M. N. and Dimara, L. 2018b. Acoustics backscattering analysis to classification and mapping of seabed substrate in Yos Sudarso Bay, Jayapura City. Jurnal Ilmu dan Teknologi Kelautan Tropis, 10(2): 291-300 [In Indonesian].

Hewitt, R. P., Watkins, J. L., Naganobu, M., Tshernyshkov, P., Brierley, A. S., Demer, D. A., Kasatkina, S., Takao, Y., Goss, C., Malyshko, A., Brandon, M. A., Kawaguchi, S., Siegel, V., Trathan, P. N., Emery, J. H., Everson, I. and Miller, D. G. M. 2002. Setting a precautionary catch limit for Antarctic krill. Oceanography, 15: 26-33.

Hjellvik, V., Michalsen, K., Aglen, A. and Nakken, O. 2003. An attempt at estimating the effective fishing height of the bottom trawl using acoustic survey recordings. ICES J. Mar. Sci., 60(5): 967-979. DOI: 10.1016/S10543139(03)00116-4.

Kim, H., Kang, D., Cho, S., Kim, M., Park, J. and Kim, K. 2018. Acoustic target strength measurements for biomass estimation of aquaculture fish, Redlip mullet (Chelon haematocheilus). Appl. Sci., 2018(8): 1536.

Labropoulou, M. and Papaconstantinou, C. 2004. Community structure and diversity of demersal fish assemblages: the role of fishery. Sci. Mar., 68: 215-226.

Lowe-McConnell, R. H. 1987. Ecological studies in tropical fish communities. Cambridge University Press, Cambridge, $\mathrm{UK}, 382 \mathrm{pp}$.

Manik, H. M. and Nurkomala, I. 2016. Measurement of target strength and fish stock in Pari Island seawaters using single echo detector method. Mar. Fish., 7(1): 69-81 [In Indonesian].

McQuinn, I. H., Simard, Y., Stroud, T. W. F., Beaulieu, J. L. and Walsh, S. J. 2005. An adaptive, integrated "acoustictrawl" survey design for Atlantic cod (Gadus morhua) with estimation of the acoustic and trawl dead zones. ICES J. Mar. Sci., 62: 93-106. doi:10.1016/j.icesjms.2004.06.023.
Mello, L. G. S. and Rose, G. A. 2009. The acoustic dead zone: theoretical $v s$ empirical estimates, and its effect on density measurements of semi-demersal fish. ICES J. Mar. Sci., 66(6): 1364-1369. https://doi.org/10.1093/icesjms/fsp099.

Melvin, G. D. 2016. Observations of in situ Atlantic Bluefin tuna (Thunnus thynnus) with $500-\mathrm{kHz}$ multibeam sonar. ICES J. Mar. Sci., 73(8): 1975-1986.

Moore, C. H., Harvey, E. S. and Niel, K. P. 2009. Spatial prediction of demersal fish distributions: enhancing our understanding of species-environment relationships. ICES J. Mar. Sci., 66: 2068-2075.

Park, Y., Seo, Y. I., Oh, T. Y., Lee, K., Zhang, H. and Kang, M. 2016. Anchovy distributional properties by time and location: using acoustic data from a primary trawl survey in the south sea of South Korea. J. Mar. Sci. Technol., 24(4): 864-875.

Parker-Stetter, S. L., Rudstam, L. G., Sullivan, P. J. and Warner, D. M. 2009. Standard operating procedures for fisheries acoustic surveys in the Great Lakes. Great Lakes Fishery Commission, Special Publication, 09-01, 168 pp.

Perangin-Angin, R., Sulistiono Kurnia, R., Fahrudin, A. and Suman, A. 2017. Community structure of demersal fish resources based on the depth of the waters in the South China Sea (Indonesia Fisheries Management Zone 711). J. Iktiol. Indones., 17(1): 67-82 [In Indonesian].

Pujiyati, S. 2008. The hydroacoustic method approach for interrelatedness analysis of sea bottom substrate type with demersal fish community. Doctoral Thesis, Bogor Agricultural University, Indonesia, 160 pp. [In Indonesian]

Pujiyati, S., Hestirianoto, T., Wulandari, P. D. and Lubis, M. Z. 2016. Fish stock estimation by using the hydroacoustic survey method in Sikka Regency waters, Indonesia. J. Fish. Livest. Prod., 4: 193.

Pujiyati, S., Wijopriono Mahiswara, Pasaribu, B. P., Jaya, I. and Manurung, D. 2007. Estimation of sea bottom reflection and fish demersal resources using hydro acoustical method. J. Lit. Perikan. Ind., 13(2): 145-155 [In Indonesian].

Rainer, S. F. and Munro, I. S. R. 1982. Demersal fish and cephalopod communities of an unexploited coastal environment in Northern Australia. Aust. J. Mar. Freshw. Res., 33(6): 1039-1055.

Samphan, P. 2016. Abundance and species composition of demersal fish, with descriptions of dominance species in Moo-Kho Bulon, Satun Province, Thailand. Int. J. Agric. Technol., 12(1): 63-73.

Simmonds, E. J. and MacLennan, D. N. 2005. Fisheries acoustics: theory and practice, $2^{\text {nd }}$ edn. Blackwell Publishing, Oxford, UK, $437 \mathrm{pp}$.

Sudhakar, V., Govindam, S., Sreedhar, U. and Kumari, B. M. 2013. Abundance, bathymetric distribution and diversity of deep sea demersal finfish resources along the south-west coast of India. Indian J. Fish., 60(4): 1-6.

Suyatna, I., Bratawinata, A. A., Sidik, A. S. and Ruchaemi, A. 2010. Demersal fishes and their distribution in estuary 
waters of Mahakam Delta, East Kalimantan. Biodiversitas, 11(4): 204-210. DOI: 10.13057/biodiv/d110407.

Tebaiy, S., Yulianda, F., Fahrudin, A. and Muchsin, I. 2014. Fish community structure at seagrass beds habitat in Youtefa Bay Jayapura, Papua. J. Iktiol. Indones, 14(1): 49-65 [In Indonesian].

Thangavelu, R., Anbarasu, M., Zala, M. S., Koya, K. M., Sreenath, K. R., Mojjada, S. K. and Shiju, P. 2012. Food and feeding habits of commercially important demersal finfishes off Veraval coast. Indian J. Fish., 59(4): 77-87.

Thompson, P. M., Brookes, K. L. and Cordes, L. S. 2015. Integrating passive acoustic and visual data to model spatial pattern of occurrence in coastal dolphins. ICES J. Mar. Sci., 72(1): 651-660. van der Kooij, J., Kupschus, S. and Scott, B. E. 2011. Delineating the habitat of demersal fish assemblages with acoustic seabed technologies. ICES J. Mar. Sci., 68: 1973-1985. DOI: $10.1093 /$ icesjms/fsr124.

Wurtzell, K. V., Baukus, A., Brown, C., Jech, J. M., Pershing, A. and Sherwood, G. D. 2016. Industry-based acoustic survey of Atlantic herring distribution and spawning dynamics in coastal marine waters. Fish. Res., 178: 71-81.

Zintzen, V., Anderson, M. J., Roberts, C. D., Harvey, E. S., Stewart, A. L. and Struthers, C. D. 2012. Diversity and composition of demersal fishes along a depth gradient assessed by baited remote underwater stereo-video. PLoS ONE, 7(10): e48522. https://doi.org/10.1371/journal.pone. 0048522 . 